\title{
Ombudsmen in Higher Education: Helping the Single Student, Contributing to the Universities’ Institutional Changes
}

\author{
Josef Leidenfrost \\ Austrian Student Ombudsman, Vienna, Austria \\ Email: josef.leidenfrost@bmwf.gv.at
}

Received June $5^{\text {th }}$, 2013; revised July $4^{\text {th }}, 2013$; accepted July $11^{\text {th }}, 2013$

\begin{abstract}
Copyright (c) 2013 Josef Leidenfrost. This is an open access article distributed under the Creative Commons Attribution License, which permits unrestricted use, distribution, and reproduction in any medium, provided the original work is properly cited.
\end{abstract}

\begin{abstract}
This article aims to firstly give a brief insight into the major challenges for modern time universities like necessary change management, growing competitiveness, increasing expectations by the stakeholders and how rising tuition fees affect all of that, and secondly on the growing pressure for universities on responding more effectively to a demanding student population, mounting expectations and diverse backgrounds of students, and thirdly how alternative dispute resolution is more and more commonly used as a means of resolving disputes and complaints informally and at an early stage in order to avoid litigation and the courts. It is described how ombudsmen in higher education can help to minimize the students' feelings of disconnection created by formal and judicial processes and get fair treatment. Catering either for students only or for the whole university community, ombudsmen provide confidential, impartial complaints handling services and also contribute to change management on the macro level and hence help with changing policies.
\end{abstract}

Keywords: University Governance; Complaint Management; Conflict Resolution; Higher Education Ombudsman

\section{Introduction}

A university, according to the Concise Oxford Dictionary, is an "educational institution designed for instruction or examination or both of students in all or many of the more important branches of advanced learning, conferring degrees in various faculties”. After centuries of relative seclusion as so-called "ivory towers", these educational institutions of advanced learning are becoming increasingly "market oriented" (Cote \& Allahan, 2007). This entails business orientation, the introduction of marketing mechanisms, and marketing strategies in higher education.

\section{Contemporary Challenges to Universities}

The contemporary university faces three major challenges: the challenge of change management due to multiple, often competing, demands; the challenge of more competitiveness; and the challenge of increasing expectations from a diverse student population, including a growing number of internationally mobile students.

Due to changing times and conditions, universities are proactively looking for students. They are therefore becoming active in vigorous recruitment and marketing activities. Their strategies are determined by competitive admission processes, which, in turn, are forming student expectations and student "behaviour" (Birtwistle, 2008).

This does not necessarily imply that students are aware what their educational needs really are. Nor does it imply that universities should change themselves to become what future stu- dents might find attractive. Such changes could well be counter the traditional concept of a university as a "universitas litterarum". There is also a danger in overselling the perceived virtues of "market oriented" universities to prospective students, no matter if they are "old" or "traditional", "new" or "modern" in the universities' own view. What is imminent to both is: the need of quality: determined by satisfaction on reliability, responsiveness, assurance, empathy, and tangibility (Turney, 1993).

\section{Mass Universities: Fees and the Perception of "Quality”}

Since by now the majority of national higher education systems worldwide have introduced tuition fees in their higher education systems, universities have to respond accordingly to quality demands.

Tuition fees have a major impact on the perception of quality. With fees come different expectations. On the organisational side, they may lead to more efficiency; they may raise also the level of services and sensitivity about more service orientation.

The increasing size of universities has stimulated the development of complex infrastructures on site, e.g. of information systems, student support services, new communications and learning technologies, etc. and the development of exchanges and cooperation with outside. At the same time, the negative sides of mass universities are also becoming more obvious: a growing anonymity within the universities, a decreasing commitment of its personnel (and probably even of its leadership), the lack of personal contact between students and professors, 
generally less commitment of universities and students to each other (Leidenfrost, 2013).

Yet another hot topic is the open access versus the selective admission of students, not to forget adequate student social support schemes and even such pragmatic issues as accommodations and residence requirements.

Higher education institutions may make promises during recruitment and not fulfil them after enrolment, simply because there are no or only vague agreements between institutions and students, since there are hardly any (detailed) contracts. No higher education institution does or can issue fully comprehensive information on the quality of its courses and programs or on the conditions of daily life and work on-site.

At classical universities, there is nothing to be bought or “consumed". Classical Universities are neither department stores (although some newer ones look alike them) nor catalogue companies (although some have very similar marketing strategies). The world of higher education is offering (continuing) education, instruction, knowledge, life-long learning, skills, last but not least, academic degrees. But: With a growing pressure on higher education institutions, they have to respond more effectively (and more quickly) to a demanding student body, to the mounting expectations and diverse backgrounds of students (Turney, 1993).

\section{If Things Go Wrong: Bring the Ombudsman in}

Students and academics are living and (inter)acting within a special sphere that has its own genuine set of codes and rules. Universities have different regulations than the "world outside", they are run and function in a different way and are therefore managed in a different way, too. It is a world of its own kind, more momentous challenges and problems can arise than just "practical” services issues which need different approaches.

Universities have a variety of formal procedures for things going wrong. These rules are often driven by their own rules and federal and state law pertaining to various issues. As a result of these formally established procedures and the timelines associated with various steps, issues and/or concerns often become cumbersome, time-consuming and/or frustrating and do not always resolve the crux of disputes. So, more and more universities have informal mechanisms to resolve issues and/or concerns.

Alternative Dispute Resolution (ADR) is such an informal mechanism, a process of resolving disputes by providing each side's needs, and adequately addressing their interests and concerns. Alternative conflict resolution aims to end conflicts before they start or, at least, before they escalate. It helps to avoid legal procedures as much as possible (Ziegenfuss \& D’Rourke, 2011).

The University Ombudsman is such an ADR instrument. An ombudsman is a person, who is in charge of representing the interests of the "ruled" against the "rulers" by investigating and addressing complaints reported by individuals (Conway \& Leidenfrost, 2010). The term arises from its use in Sweden, with the Parliamentary Ombudsman instituted there in 1809 to safeguard the rights of citizens by establishing a supervisory agency independent of the executive branch. The word and its specific meaning have since been adopted into English as well as other languages.

An academic or university, or more general: higher education institution (HEI) ombudsman, is an independent, neutral person to whom students, staff, faculty and/or administrators can turn in an informal and confidential manner for help with their complaints about the HEI and its community. He aims at resolving problems in an informal manner, primarily through mediation. Another important task is to identify structural problems and making recommendations to responsible authorities to prevent similar problems in the future. HEI ombudsmen's main working principles are those for independence, impartiality, neutrality, and confidentiality.

HEI ombudsmen are set up by the institutions themselves or are mandatory under the respective higher education legislations.

Universities first started to have ombudsmen in Canada in 1965, soon after that in the United States (Conway, 2013). Now they are part of many higher education systems around the world. Ombudsmen's experiences are highlighting and can help raising awareness towards manifold problems as they arise. Their feedback helps the decision makers to carry out changes and adaptations within the complex system of a university.

In the process-focused formal channels, students' perceptions and beliefs (being the "weaker element") may be dismissed as unimportant to the process due to the "lack of probative value" or due to the "tendency to confuse the issues". Alternative dispute resolution through ombudsmen focuses more on resolution, relationships, and interpersonal communication. Ombudsman services for students are nowadays set up in order to minimize the students' feelings of disconnection created by traditional judicial processes and to offer alternative treatment especially for academic issues. In some European countries (like in Spain) ombudsmen are in charge of all members of the university, and are compulsory under the law.

\section{Higher Education Ombudsmen: Helping to Change Governance}

Controlling the proper, correct and quick appliance of regulations is one main task of academic ombudsmen. The other one is helping to get fair treatment, mainly through mediation in opposition to any legal settlement of disputes and conflicts before the courts. Mediation as a voluntary and informal process where an acceptable third party, the mediator (ombudsman) helps disputants to resolve their differences in a doable and durable agreement (Leidenfrost, 2013).

The ombudsmen being active within national and international higher education are mostly sharing transferable principles like their independence from the country's government and the institution's leadership. Ideally, the universities and the students themselves as such are supposed to "own" the position of the ombudsman.

Depending for whom they cater, ombudsman offices provide confidential, impartial complaint handling services to students, staff, faculty and administrators. They assist with complaints involving interpersonal misunderstandings or disputes as well as those with complaints about academic or administrative issues.

The role of an ombudsman office includes:

- listening and discussing questions, concerns, and complaints;

- helping evaluate various options to address concerns;

- answering questions or help find others who can;

- explaining university policies and procedures;

- advising individuals about steps to resolve problems informally; 


\section{J. LEIDENFROST}

- advising individuals about formal and administrative options;

- mediating disputes to seek resolution of problems;

- making appropriate referrals when informal options don't work;

- pointing out patterns of problems/complaints to administrators/decision makers or bodies at the institution.

These manifold roles lead to three main vital functions for ombudsmen: problem assistance, organizational critical selfanalysis and changing an institution's governance (Conway \& Leidenfrost, 2010).

Attribute to changes through the work of ombudsmen, the defence of the "ruled" from the "rulers" through investigation and addressing complaints, results from a complex interplay of emotions and cognitive processes of all people involved.

Change management, the process of developing a planned approach to changes inside organizations, can be akin to opportunity, rejuvenation, progress, innovation, and growth, but also to instability, upheaval, unpredictability, threat and disorientation. Whether members of a university perceive changes with fear, anxiety and demoralisation or with excitement and confidence depends on institutional governance.

If change management is a planned process for changes then ombudsing is an apt tool for such changes needed in the universities' macro environment in times of massification and increasing competitiveness of higher education.

Universities should clarify and make it publicly known the roles and responsiveness of its many actors to provide the students and the general public with accountability. Information concerning the organisation and changes within then organisation should be timely and balanced to ensure that all members of the university have access to clear, factual information.

If a university is to thrive and be responsive to a diverse set of voices, it is well advised to have an ombudsman office to assist the university leadership in fulfilling its missions-with all of its constituencies, also internationally.

Ombudsman services "humanize" institutions for many constituents. The existence of an ombudsman sends the message that the institution cares about its people and recognizes the value of providing informal dispute resolution for members of the campus and the international community (Karp \& Allena, 2004).

\section{REFERENCES}

Birtwistle, T. (2008). Legal aspects of higher education in an international context: Disputes, resolutions, methods and safeguards. Amsterdam: EAIE Occasional Papers

Conway, M., \& Leidenfrost, J. (Eds.) (2010). Common objectivesDifferent pathway: Embedding ombudsman principles and practices into higher education institutions. Vienna: Ministry of Science and Research

Coté, J. E., \& Allahan, A. L. (2007). Ivory tower blues. A university system in crisis. Torotno: University of Toronto Press.

Howard, C. L. (2010). The organizational ombudsman. Origins, roles, and operations. A legal guide. Chicago: American Bar Association.

Karp, D., \& Allena, T. (2004). Restorative justice on the college campus. Promoting students growth and responsibility and reawakening the spirit of campus community. Springfield, IL; Charles C. Thomas Publishers.

Leidenfrost, J. (Coming Up in 2014). Non-hierarchical conflict resolution in higher education: In-house mediation as a tool. Vienna: Ministry of Science and Research

Turney, W. G. (1993). The responsive university. Restructuring for high performance. Baltimore: Hopkins University Press.

Ziegenfuss Jr., J. T., \& D’Rourke, P. (2011). The ombudsman handbook. Designing and managing an effective problem-solving programme. Jefferson, NC: McFarland. 